\title{
Candida Biofilms and Some Strategies for Prevention
}

\author{
Janaina de Cássia Orlandi Sardi* \\ Faculty of Pharmaceutical Sciences of Department of Clinical Analysis, Laboratory of Clinical Mycology, Univ Paulista (UNESP), Brazil
}

Biofilm formation by fungal and bacterial pathogens on implanted medical devices causes major morbidity and mortality among patients, and leads to billions of dollars in healthcare cost. There are estimated to be more than 45 million medical devices implanted every year in the United States. Infection of these devices occurs in $60 \%$ of patients, and Candida species are responsible for up to $20 \%$ of these infections [1]. Biofilms are complex structures are highly resistant to antimicrobial agents and the host immune system. These cells biofilm, have an altered phenotype with respect to growth rate and gene transcription [2]. Studies have shown that the microorganisms are almost nonexistent in their planktonic free form in the tissues of the host, but are grouped together, forming a multicellular community, both in tissues and on prostheses, catheters and other surfaces [3]. Transplantation procedures, immunosuppression, the use of indwelling devices and prolonged intensive care unit stays have increased the prevalence of fungal disease Availability to the inside of medical devices, such as central and peripheral catheters, haemodialysis and peritoneal dialysis units and intracardiac prosthetic valves, facilitates biofilm formation [4]. Biofilm present in the dental plaque was the first to be recognized by the medical community in the 1960s [5]. The formation and accumulation of biofilm on substrates in the oral cavity is the main etiologic factor of oral diseases, candidiasis is one of the most common fungal oral infections diagnosed in humans, with a prevalence of up to $75 \%$ in prosthesis users [6]. Patients who underwent hemodialysis and peritoneal dialysis are commonly affected by infections caused by the presence of biofilm [7]. The Candida yeasts are among the main microorganisms isolated from patients with cancer, possibly due to infection with the use of implanted devices for intravenous access. The mechanisms of resistance of the biofilm include extracellular matrix (ECM), efflux pump activity, persisters, cell density, overexpression of drug targets, stress responses, and the general physiology of the cell [8]. Thus, to increase the efficiency of new treatment strategies against bacterial and fungal infections, factors that lead to biofilm growth inhibition, biofilm disruption, or biofilm eradication are being sought. These factors could include enzymes, sodium salts, metal nanoparticles, antibiotics, acids, chitosan derivatives, or plant extracts. Thus, strategies aiming the search for eradicating the biofilms are necessary [9]. More recently, the use of silver nanoparticles (AgNPs) has been suggested for coating medical titanium implants in the hope of inhibiting biofilm formation and thereby reducing the incidence of microbial infections and rejection [10]. Anti-Candida antibodies can reduce the binding of Candida to various surfaces [11]. Studies with antibodies have been performed by various authors to test their effects on various fungal and bacterial organisms. The application of photodynamic therapy has been investigated regarding its inactivation of micro-organisms that are pathogenic to the human host. Several authors have associated light emitting diodes (LEDs) with other substances [12]. More studies have been performed with gold nanoparticle and enhanced photodynamic therapy including the use of methylene blue against recalcitrant pathogenic C. albicans biofilms [13]. Also, because the biofilm matrix is composed of DNA, proteins, and extracellular polysaccharides, recent studies have indicated that the disruption of the biofilm structure could be achieved via degradation of individual biofilm compounds by several enzymes such as DNAse, lactonases, $\boldsymbol{\alpha}$-amylases [9].
The development of strategies to combat microorganism growing in biofilms is yet a challenging task these bacterial and fungal are much more resistant to classical antimicrobial therapies. Although there are several studies to seek the destruction and removal of biofilms, many studies will be necessary and the way is hard.

\section{References}

1. Sardi JC, Scorzoni L, Bernardi T, Fusco-Almeida AM, Mendes Giannini MJ (2013) Candida species: current epidemiology, pathogenicity, biofilm formation, natural antifungal products and new therapeutic options. J Med Microbiol 62 : 10-24.

2. Donlan RM, Costerton JW (2002) Biofilms: survival mechanisms of clinically relevant microorganisms. Clin Microbiol Rev 15: 167-193.

3. Soll DR (2008) Candida biofilms: is adhesion sexy? Curr Biol 18: R717-720.

4. Mukherjee PK, Chandra J (2004) Candida biofilm resistance. Drug Resist Updat 7: 301-309.

5. Potera C (1999) Forging a link between biofilms and disease. Science 283 : 1837, 1839.

6. Dutronc H, Dauchy FA, Cazanave C, Rougie C, Lafarie-Castet S, et al. (2010) Candida prosthetic infections: case series and literature review. Scand J Infect Dis 42: 890-895.

7. Pires RH, Santos JM, Zaia JE, Martins CH, Mendes-Giannini MJ (2011) Candida parapsilosis complex water isolates from a haemodialysis unit: biofilm production and in vitro evaluation of the use of clinical antifungals. Mem Inst Oswaldo Cruz 106: 646-654.

8. Ramage G, Rajendran R, Sherry L, Williams C (2012) Fungal biofilm resistance. Int J Microbiol 2012: 528521.

9. Taraszkiewicz A, Fila G, Grinholc M, Nakonieczna J (2013) Innovative strategies to overcome biofilm resistance. Biomed Res Int 2013: 150653.

10. Huang T, Cao W, Elsayed-Ali HE, Xu XH (2012) High-throughput ultrasensitive characterization of chemical, structural and plasmonic properties of EBLfabricated single silver nanoparticles. Nanoscale 4: 380-385.

11. Bujdáková H, Paulovicová E, Borecká-Melkusová S, Gasperík J, Kucharíková $\mathrm{S}$, et al. (2008) Antibody response to the $45 \mathrm{kDa}$ Candida albicans antigen in an animal model and potential role of the antigen in adherence. J Med Microbiol 57: $1466-1472$.

12. Pereira CA, Costa AC, Carreira CM, Junqueira JC, Jorge AO (2013) Photodynamic inactivation of Streptococcus mutans and Streptococcus sanguinis biofilms in vitro. Lasers Med Sci 28: 859-864.

13. Khan S, Alam F, Azam A, Khan AU (2012) Gold nanoparticles enhance methylene blue-induced photodynamic therapy: a novel therapeutic approach to inhibit Candida albicans biofilm. Int J Nanomedicine 7: 3245-3257.

*Corresponding author: Janaina de Cássia Orlandi Sardi, Faculty of Pharmaceutical Sciences of Department of Clinical Analysis, Laboratory of Clinical Mycology, Univ Paulista (UNESP), Brazil, Tel: +55 163301 5716; E-mail: janaina-sardi@uol.com.br

Received November 17, 2013; Accepted November 19, 2013; Published November 28, 2013

Citation: de Cássia Orlandi Sardi J (2013) Candida Biofilms and Some Strategies for Prevention. Clin Microbial 2: e115. doi:10.4172/2327-5073.1000e1115

Copyright: (C) 2013 de Cássia Orlandi Sardi J. This is an open-access article distributed under the terms of the Creative Commons Attribution License, which permits unrestricted use, distribution, and reproduction in any medium, provided the original author and source are credited. 